SALAM; Jurnal Sosial \& Budaya Syar-i

FSH UIN Syarif Hidayatullah Jakarta

Vol. 7 No. 11 (2020), pp. 1073-1088, DOl: 10.15408/sjsbs.v7i12.18292

\title{
Interest Loan in The Perspective of Islamic Jurisprudence; (Comparative Studies) *
}

\author{
Daud Rasyid ${ }^{1}$ \\ UIN Syarif Hidayatullah Jakarta \\ DPK Universitas Islam As-Syafiiyah Jakarta \\ d. \\ $\underline{10.15408 / \text { sjsbs.v7i12.18292 }}$
}

\begin{abstract}
Trading is a fabric of our lives, where lending and borrowing has become a contemporaneous product. What remains constantly changing is the models and means in the transaction. In this day and age, banks issues loans through credit cards to clients for financial transactions with fixed maturity dates and balance limits. Cardholders will be penalized for late payment should the due amount is not settled within the given grace period. Another example in trading activity is when a company seeks public loan funding to cover investment projects. The capital transaction is offered in an exchange of returns in interests and derivatives awarded to participating clients for certain contract durations. These are called interest-based banks. Since the beginning of Islam, Prophet Muhammad, Peace be upon him, prohibited this practice, which at the time was engaged by his uncle, Al-Abbas. Prophet Muhammad, Peace be upon him, firmly said: "The first usury I eliminated was the usury belonging to my uncle al-Abbâs". Islamic Sharia strictly forbids charging additional fees for loans given to borrowers. What is permissible is a business agreement is via capital cooperation and profit-sharing, following a mutual contract, and not by levying loan charges in form of additional fees. This paper examines the problems from the perspectives of Islamic law by presenting the opinions of the schools of Fiqh and making comparisons based on the literature from each school of thought.
\end{abstract}

Keywords: Loan, Interest, Ribâ, Syarî'at, Companion of Prophet

\begin{abstract}
Abstrak:
Dalam interaksi dagang, pinjam-meminjam tidak dapat dilepaskan dari aktifitas manusia. Sejak dulu model ini sudah ada sezaman dengan keberadaan manusia. Yang berubah hanya sarana dan model. Di zaman ini, pinjaman bank berupa kartu kredit yang memberikan pinjaman dana kepada nasabahnya untuk dipakai dalam transaksi keuangan dengan limit tertentu dan jangka waktu tertentu. Apabila waktu yang ditetapkan berakhir, maka nasabah dikenakan denda dengan kewajiban membayar uang yang dipinjamkan ditambah denda atas keterlambatan. Contoh lain, perusahaan besar membutuhkan dana besar untuk proyek bisnisnya. Ia memerlukan tambahan modal, lalu menawarkan kepada public untuk memberikan pinjaman dalam waktu yang ditentukan dengan perjanjian akan memberi imbalan berupa "bunga" atas keikut-sertaan itu. Inilah yang disebut dengan pinjaman berbunga. Sejak awal Islam, praktik ini dilarang oleh Rasul yang dulu dijalankan oleh pamannya sendiri al-Abbas. Dengan tegas Rasul mengatakan: "Riba pertama yang kuhapus ialah riba pamanku al-Abbas". Syari'at Islam melarang keras untuk mengenakan biaya tambahan atas pinjaman yang diberikan kepada peminjam. Yang dibolehkan ialah perjanjian bisnis dengan bentuk kerjasama permodalan dan pembagian keuntungan sesuai kesepakatan, bukan pembebanan atas pinjaman dengan mengenakan tambahan biaya atas pinjaman. Makalah ini menelaah masalah tersebut dari sudut pandang Hukum Islam dengan menampilkan pendapat mazhab-mazhab Fiqh dan melakukan perbandingan berdasarkan literatur masing-masing mazhab.
\end{abstract}

Kata kunci : Pinjaman, Riba, Bunga, Syari'at, Sahabat Nabi.

* Received: July 13, 2020, Revision: July 18, 2020, Published: December 5, 2020.

${ }^{1}$ Daud Rasyid adalah Dosen pada UIN Syarif Hidayatullah jakarta dan DPK Universitas Islam As-Syafiiyah Jakarta. Email: daud.rasyid@uinjkt.ac.id 


\section{A. INTRODUCTION}

Interest (Ribâ) can occur in a loan or sales purchase 'aqd (contract). For instance, a person lends money on a pre-determined condition to increase payment over the face value of the original amount from a borrower. When tied to customs, the return is later paid in premium with cash, either monthly or yearly, and can involve local practices. This type of transaction is commonly known in conventional banks and merchants, as well as, traders who manage the assets /capital investment of others.

The interest of such an example has been occurring since the jâhiliyah era. It is a period when the lender requests for due payment at pre-assigned terms of loan maturity yet the borrower fails to oblige in paying on time. Consequently, the lender imposes unfavorable conditions at the expense of the borrower, by charging multiple yearly interest rates. This practice of wealth accumulation occurs at interest-based conventional banks when borrowers (individuals or banks) are unable to clear debts along with added interests from the previous year.

\section{B. METHODS}

The research methodology used in this study is a reflective exploration to examine and analyze deeper the rationales on the prohibition of Riba. The approach compares historical concepts and interests against contemporary interpretations. The overwhelmingly widespread of unlawful wealth accumulations occurring in loan interests or sales purchase in today's financial systems, only amplify the preexisting knowledge and faith in the Qur' an and Hadith as an absolute command to avoid the practices, all together.

\section{ANALYSIS AND DISCUSSION}

\section{Understanding Interest Loan}

"Interest loan" in Islamic jurisprudence denotes the increment in the loan based on agreed condition/additions in favor of the lender. For example, when lending money or seeds/commodities, a monthly extension is pushed beyond the date of maturity, causing due payment to be rendered at extra cost, either in form of a specified amount, percentage, or with tangible item, benefit, and service. The borrower grants facilities only for the sake of collateral, by proving the lender with free amenities until full repayment is made, such as usage of his or her house to live and to plot land for farming or even to provide for clothing. Ribâ under the Sharî̀a (Islamic laws) compliant translates into excess compensation in lending or borrowing. It is a concept that is prohibited by the Qur'an and Sunnah (Prophetic example). The aspect in gaining benefits from lending money or receiving money is thereby haram, according to the companion ulamas (Ijmâ' or consensus of scholarly companion). (al Bayhaqy, $1412 \mathrm{H}$ / 1991M, 8/168).

The widespread of Ribâ does not make it permissible. Allowing a preset condition in lending for exchange of excessive profits constitutes as haram or prohibited. 
There is no dissenting opinion from the ulamas based on the Qur'an, Sunnah, and Ijma (consensus amongst Muslim jurists on the particular legal issue). (Al-Kasani, 1417 H/1996 M, 7/395). A loan contract is an Irfâq agreement - which encourages the act of kindness in helping willingly those in need - without imposing any condition that would otherwise amount to accumulated benefits or excess in service delivery that the lender extends to the borrower.

An example of pre-required conditions in lending is by making it mandatory for the borrower to return the loan in excess amount or better offer. The lender may well be allowed to stay at a house belonging to the borrower during the loan period. Another example is by enforcing the borrower to sell the asset to the lender, including land property, vehicle, or even permission to farm for free on a borrower's land for as long as the debt is not yet settled. In addition to the mounting extra costs of lending, there is also interest rates from a conventional bank. All of these accumulated additions are haram due to ribâ; they stipulate extra wealth over something with no values. Avoiding ribâ is therefore mandatory, as narrated by Ibnu Qudâmah $(1988,3 / 304)$ in "AlMughny": "Every lending with required addition is haram according to the opinions of the ulamas."

A loan transaction without any required conditions involving voluntary giving from the lender - regardless of quality or quantity - is permissible by all ulamas except for Maliki Madzhab (Ibnu Habib). (al-Dardîr, 3/295; Ibnu Juzay, 288; al-Syarbiny, 2/119; al-Syirazy, 1/304; Ibnu Qudama, 3/304,321). The underlying reasoning is that the transaction does not constitute ribâ. Voluntary giving for the sake of benevolence is highly encouraged by Prophet Muhammad, Peace be upon him, as narrated in a hadith: "the best among you are those who do better in repayment." (al-Bukhary, 1422 H, 3/117; al-Nasa'i, 1421 H/ 2001 M, 6/90; etc).

Jâbir r.a, who was a companion of Prophet Muhammad, Peace be upon him, said: "I came to Prophet Muhammad, Peace be upon him when at that time he owed me. He repaid me the debt and gave me an extra amount." (Muttafaq 'alayh) That extra over and above the loan was not stipulated on the debtor as a requirement in repayment. Ibnu Qudamah (4/321) said, "If a lender in the absolute term does not declare any condition attached to the loan, and the debt is later cleared in repayment above the original amount or value as agreed by two parties involved, then the transaction is permissible. Such is also valid in a case when the borrower, who is residing in another country, writes a check to settle the loan."

In a case of gift and loan, when it is given to a borrower in exchange for a certain extended amount of time to repay the debt, or when there occurs intention to bribe the lender or even when there is service rendered to the lender in exchange of the loan - all are considered haram. Al-Bukhâry narrated in his "al-Târîkh" (al-Bukhâry, 275 no. 2297) that Anas ibn Malik reported that The Prophet, Peace is upon him, said: "If a man extends a loan to someone, he should not accept a gift." 3. Meanwhile, it also constitutes a harmless gift when the borrower and lender have been previously accustomed to exchanging such favors mutually, where otherwise, it is an absolute prohibition since it is haram to accept gifts (Mâliky's madzhab). Lending and borrowing are supposed to 
serve as helping each other, therefore, this act of kindness, charitable posture, and ease is encouraged in a case of voluntary debt forgiveness.

On contrary, when a "Qardh" (lending and borrowing) requires the return of payment in a smaller amount than the original loan, then this is not permissible regardless of whether the borrowed item is money or commodities, because the debt has to be repaid in equivalence. Decreasing or increasing the value is against the requirements in lending transactions (Ibnu Qudâma, 4/322-323).

When lending old and crumbled bill and it is later returned in new crisp money without prior consent, it is then permissible. However, it is ribâ when repaying the borrowed money with a lesser currency value as it constitutes an exchanging item with a lower value. (Ibnu Qudâma, 4/322-323). In contract provisions, Ibnu al-Munzir wrote that "All ulamas that we know of agree that any remuneration collected from a kafâlah contract (sales of debt with debt) is not halal and not permissible." Loan repayment can be settled with the value of the loan, and every loaned item must be in equivalent weight, type, size, and characteristics.

Because of Hanbaly, that in a case when the borrower pays the lender back with something that is not weighed or measured, there are two opinions:

First: It is mandatory to repay the value of the loaned item because there is no substitute and therefore must be exchanged at an equivalent price, just as in a case of damages. This is a zhâhir (apparent meaning) opinion.

Second: it is mandatory to repay in equivalent value closest to the original when lending occurs, because Prophet Muhammad, Peace is upon him, borrowed a young camel of a certain age from a man who came to demand it back and ordered a companion to give it to him, but there were only older camels available. Prophet Muhammad, Peace be upon him, told the companion to give it to the man. This is different from the case of damaged products when the price value is required since it is considered as value protection, whereas in loans it is more mitigating.

The resolutions and recommendations of the 12th session of the Islamic Fiqh Conference no. $110 / 9 / 12^{\text {th }} 1421 \mathrm{H} / 2000 \mathrm{M}$ and its decisions no. 42 , concerning Currency Rates Fluctuation, resolves "It is significant that a fixed debt is repaid in its currency and not by its counter-value, because debts are settled in the same currency. Thus it is not permitted to attach fixed debt, whatever their source, to currency fluctuation."

\section{Every act of lending which attracts benefit is Ribâ}

The loan is supposed to be provided as a means to help each other in all aspects of life, to ease the burden of hardship, and should not justify as means for making a living nor as commercial facilitation. Therefore, a loan must be paid off at face value following Islamic law: "All lending which attracts benefits are ribâ." In this context, the gained benefit is part of a pre-agreed condition, which over time turns into a customary practice. 
Conversely, should the gained benefit be levied without pre-agreed conditions nor it is treated as a customary practice, the lender is permitted to receive payment along with additions from the willing borrower. In this case, the borrower returns the loan in a better quality of the original loan's value, more in quantities or by selling his or her house. Referring to the hadiths from Imam Ahmad, Muslim, the transaction becomes lawful (permissible) as long as such conditions are discussed in advance between the two parties involved.

From Abi Rafi's narration, "Prophet Muhammad, Peace be upon him, borrowed a young camel from a man, and when he received Shadaqa of camels, he ordered me to repay the man his young camel but I couldn't find anything except for a healthy Ruba'iy camel at an age nearing pregnancy (seven years old). Prophet Muhammad, Peace be upon him, replied, 'Give it to him, truly the best of men are best of those in repayments,'”' According to hadiths of Ahmad, Bukhâri, and Muslim, Jâbir bin Abdillâh narrated, "When Prophet Muhammad, Peace be upon him, owed me, he paid back with addition."

\section{Interest Loan Law and Consensus of Ulama}

Ulamas differ in opinions relating interest loan:

\section{a. Allowing Interest Loan (lending and borrowing)}

This opinion derives from an ulama in India during the early last decade. As noted in an article published by the Haydar Abad authority in India relating to this very topic (not a generalized argument but an individual rationale) that allows for an interest-based loan (Ribâ Qardh). The ulama seems to take on daily (reasoning) from the Hanafy Mazhab, which states that the Qur'an's verses mention ribâ in general terms. The Sunnah, on the other hand, provides explanations and translations. The Prophetic saying only denotes ribâ prohibition (haram) on sales purchase and permits ribâ on loan.

b. Strictly prohibited (harâm) only for consumptive loans but not for productive loans

The opinions of some Ulamas state that Ribâwi loan used for consumption is a prohibited ribâ (unlawful usury). Whereas what is consumed in investment and production is not haram. The reason for forbidding usury is oppression and must be avoided. However, oppression can occur in the case of consumptive loans, where borrowers need to fulfill their basic rights, such as eating, drinking, clothing, shelter, etc. Besides, when a person makes a conventional loan due to an emergency, such borrower does not engage in a loan transaction in an attempt to develop a business and generate profit. Doing so would translate into an act of oppression, which is unlawful or haram. A borrower is a weak party who cannot protect himself or herself from loan sharks. Islam on the other hand protects a weaker party. Subsequently making the consumptive loan forbidden usury.

\section{c. Multiple interests in ribâ are haram}

Some scholars believe that the unlawful usury involves ribâ which accumulates multiple interests or excess leading to oppression. Conversely, it is not haram in a case of smaller or lesser usury without explicit oppressive nature nor intending to expand benefits. 


\section{d. Ribâ lending is not the origin of a prohibited contract}

People who believe in this opinion view that ribâ loans are not the basis of a prohibited contract. They say the origin of the forbidden contract is a contract for buying and selling. Meanwhile, a contract for a loan is only a product of qiyas for the sale and purchase agreement. This opinion does not imply that it is legal for a ribâ loan but merely suggests that: a ribâ loan is not the origin of a prohibited contract.

\section{e. Loans may interest at the time of need}

This opinion arises based on the results of the fatwa issued by Muhammad Syaltût when asked about the loan law with interest, and the law of borrowing between countries, or between countries and the people, in addition to the law of stocks and valuable papers (checks). Then he replied: manifestly the Qur'an compilation forbids usury to the believers, he determines it based on customs or local practices. A lender bills the loan to the borrower at the agreed time, who in turn asks the borrower to postpone paying extra on top of the due balance. Once both parties agreed, the ribâ multiplies. And Allah condemns it. Such incident generally happens between the poor and rich, who are inclined to monopolize human needs without consideration nor compassion. Islam on the other hand strongly promotes the act of benevolence when building a society. And ribâ does not honor the rights of individuals.

\section{f. Interest-base lending for needs}

Interest rate is part of an economic system which enforces savings as collateral to nonperforming fund. Many are reluctant to put money in the banks due to a notion of adverse impacts in unlawful interest rates. Maximizing the use of the banks' interests is through allocating the funds in sectors of industry, agriculture, and trade. Each production sector will grow dividends exponentially. The reasons behind having limited employees and resources supply are based on thinking that maximizing the potentials on small scale savings without fear of losing to a larger scale will result in two types of interests, such as private saving funds and production output.

\section{g. Benefits from safe depository box are permissible}

It is halal to gain profits derived from the safe deposit box. The secured wealth is not a loan received from the owner of the assets of whom willingly and without coercion grants the safe deposit box facilitator his or her deposit as an investment in various business sectors. And most of the time if not rarely, will a bankruptcy or other losses take place. The owner of the assets ensures that his or her deposit will not go in vain by routinely ensuring to check on the status of the wealth and by increasing more assets into the account that would eventually boost the transaction and drives greater benefits. Additionally, other parties who will enjoy the positive returns include the workers, employees, and government. (Syaltût, 351-352)

\section{Arguments on the prohibition of Interest Loan}

An illustration of a form of interest loan is when a person gives a loan along with conditions, which include a charge for higher repayment or service delivery that would 
allow the lender rights to live in the borrower's house - this constitutes haram based on ijma. (Burhanuddin, 1418 H/1997 M., 4/209, al-Haitsami, 1407 H/1987 M, 1/80, Âlu alShaykh, 16). The purpose of lending and borrowing is for an act of kindness in helping each other and benevolence, as well as to become closer to Allah almighty. The supporting argument (dalîl) validating unlawful loan (al-qardh) are as follow:

a. The Qur'ân and hadîth prohibiting ribâ

b. Specific hadith condemning the practice of Ribâ Qardh. Prophet Muhammad, Peace be upon him, as narrated by Ibnu Mâjah (4/84), said: Meaning: “When one of you grants a loan and the borrower offers him a gift or a ride on a transportation, he should not ride, unless the two of them have been previously accustomed to exchanging such favors mutually."

c. Several âtsâr (quotes and action from Prophet's companions) supporting these hadîts (Burhanuddin, 4/209):

d. Fatwa (rulings) from companions condemning ribâ qardh, Umar, Abdullah ibn Umar, Abdullah ibn Mas'ud, Abdullah ibn Salâm, Ubay ibn Ka'ab, Ibnu 'Abbâs and Fadhâlah ibn 'ubaid. (ibid)

e. Ijma', countless narratives from the ulamas. (ibid)

However, if the profit or benefit gained by the lenders from the borrower was accumulated without attaching any preconditions, then the transaction would be permissible. The dalil is based on the experience of Prophet Muhammad, Peace be upon him, who owed Bakr RA. He returned it with something better and said: "For the best among you are those who repay their debts handsomely." (al-Bukhâry, 3/99). However, Imam Malik was in the view that it is not forbidden although reportedly was very much in dislike. (Ibnu 'Abdi al-Bar, 1400H/1980M, 727-728). Al-Syawkani c ommentedon the opinion of Imam Mâlik by saying: "Their opinions (Mâlikiyah school) are refuted by the hadiths of Jâbir, noting: (( أنيت النبي صلى الله عليه وسلم وكان لي عليه دين فقضاني وزادني ())

Meaning: "I came to Prophet, Peace be upon him, and he said he owed me money, thus he paid it with extra." (al-Bukhâry, 1/96)

This hadith clearly expressed that Prophet Muhammad, Peace is upon him, when repaying with the added amount. It is rightfully so (zhâhir) in that such addition is in volume and not in quality. In shahîh Al-Bukhari (3/117), Prophet Muhammad, peace be upon him added one qirâth (portion).

The added transaction is valid for as long as it is conducted when settling the debt. It is absolutely haram, however, when done prior or even by giving a gift to the lender before the date of debt maturity. Ibnu Taimiyah (5/394) said: "The Prophet, Peace be upon him, and his companions prohibited lender to receive a gift from the borrower before the date of debt maturity because the gift is intended to delay payment date, although it was not discussed during the beginning of the contract".

Conversely, it is not haram when the gift is given after the loan is paid back in full or to pay an extra amount over the face value of the original loan. 
Whoever does not honor those intentions by allowing the receiving and giving gift before settling the debt, he or she unequivocally does not conform with Prophet Muhammad, Peace be upon him. Ibnu al-Qayyim said: "Prophet Muhammad, Peace be upon him, and his companions forbid lender to receive a gift from the borrower before the debt matures. This is to prevent ribâ, because the gift was not discussed earlier at the beginning of the loan contract that would serve to delay the date of payment.

Additionally, Asy Syawkani (3/231) supported a similar view on ribâ, explaining, "Every loan or debt alike (given by the borrower to the lender) if intended to delay payment or to bribe lender or to allow lender for profit-making in the accruing revenues from the debt, such transaction is deemed haram, because it is ribâ and bribery." The hadith of the Prophet, Peace be upon him, underscored the narration above when he said: إلا أن يكون جرى بينه وبينه قبل ذلك). Which means: "unless the two of them have been previously accustomed to exchanging such favors mutually."

In summary, every profit earning (accrued revenue) at the borrower's expense can be classified as follow:

a. It is haram if disclosed as a condition, either before and posts the payment

b. It is permissible to allow for accrued revenue post repayment if it is not recorded as the contract's condition or pre-agreement. When received before settling the debt, it is permissible as well only if it is noted as the gift of which both parties have been previously exchanging mutually.

\section{Lending and Borrowing Involving Ribâ and Today's Transaction}

\section{a. Bank Interest}

Economists refer to bank interest as a cash fund, which involves payment of an additional amount on the principal/debt that is given by the bank or safe depository box due to a deposit/savings activity. The interest is the most common form of ribâ, which is strictly forbidden in Islam and haram based on the Qur'an, Hadiths, and Ijma.

According to a narrative, there is an Ijma on the unlawful lending's condition resulting in accumulating increased repayment. (Ibnu Hazm, 8/494, Ibnu Qudāmah, 4/354) What the scholars refer to is that debt is not a loan, but it is sales purchase of fund incurred up to a specific time frame as narrated by Mufti of Saudi Arabiya, Muhammad ibn Ibrahim (7): "What is said about lending and borrowing is not lending and borrowing, because the objective is to conduct good deeds to others and as a form of kindness towards mankind. In this sense, what they meant as lending and borrowing is essentially a mu'awadhoh or a mutual agreement (with the intension to gain profit) since this kind of transaction is similar to selling and buying one dirham with few dirham, which is equivalent to ending the repayment with excess in profit as part of a predetermined condition.

Bank interest was taken by a bank institute over the given debt or what a bank pays to the bank account holder is exactly similar to ribâ. Both transactions constitute an excess/addition, consequently making ribâ equivalent to bank interest. 
As we have noted earlier, the illegality of the loan is due to additions to the payment of good debts. The ruling is from the Qur'an, Sunnah or Ijma ', and it includes all the benefits that the lender requires to the debtor, as the purpose of the loan is to the debtor and that he may take advantage of the debt. The purpose of the debt is not to profit and to repay, so the debt is treated as a loan. And the prophet Muhammad calls it manîhat wariq (ورق منيحة) which men's grace and mercy. It is as if he lent a few dirhams and then returned to him the amount he borrowed (not a few dirhams). It was repaid with the loan amount. This was like a man doing good to others in allowing to use his property (such as a car, home) for the person to take advantage of the property, and then he must return the property to the owner (Ibnu Taymiyah, 1427H/ 2006 M, 3/146-147), So on this basis, any debt with interest practiced by the bank in the present day is usurped by Allah Almighty and Rosul. -Yes and threatened by the world's painful and misleading point, because when banks do debt transactions between banks and people with an urgent need, merchants, factory owners or their company requires that the borrower pays interest whose amount depends on how much the amount of debt and the amount of this interest will increase if there is a delay in repayment of the debt from a specified time, and here there are two types of usury practices, usury fadhl and usury nasi ah (Sa'ud ibn Duraib, 51-52). Allah Almighty said:

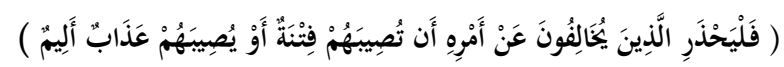

Meaning: "then let those who disobey Prophet Muhammad, Peace be upon him, be fearful of the tribulation or a painful adzab."

\section{b. Bond}

A bond is a document containing a contract or agreement from a bank or a company that requires the bondholder to pay a certain amount of funds at a predetermined time to gain a predetermined profit. The burden of debt $s$ on the company, government, or individual investor. Companies need a large number of funds to expand their reach that is paid periodically for a long period. Since no one is willing to provide, one way to resolve the situation is by issuing bonds and to market them to the public in the amount that would support the financing of the investment. Every bond has its benefit and incurred yearly interest rates for up to specified maturity dates. The bondholders' fund will eventually be returned to the buyers. ('Umar ibn 'Abdul Aziz, 1418H, 369).

For example, PT JASAMARGA Tbk or PT INDOSAT wants to expand its company network. The company will require huge funding, and this desire is difficult to materialize except by issuing bonds. Therefore, the company issues bonds and market them to the public, whereas bondholders, would receive monthly profits within five years' terms. After five years, the company will return the funds borrowed from the bondholders.

From the practice of issuing bonds by companies or governments, it is clear that bonds are usury, and there is no doubt that they are ribâ qordh, and must be avoided even though bonds are called investments.

We must understand the difference between bonds and stocks: 
- Shares are included as part of the capital itself, while bonds are the responsibility of the company's forest, the company is the party that owes the bondholders

- Shares are not returned unless the company is liquidated, while the bonds are returned according to the agreed time

- Shareholders are one of the owners of the company, so there is a possibility of profit and loss following the company's turnover, bankruptcy, or profitability. Yet, profits are not restricted. The profits and losses of the company are shared and shared equally by the shareholders. The bondholder will get a fixed profit following the number of funds he provided to the company and does not suffer any losses.

- Bondholders get priority rights when the company experiences liquidation because bonds are included in the company's debt, while shareholders do not get this right. And what is a relief for a Muslim today is the issuance of shariah bonds issued by Arab countries, whose practice was initially followed by some eastern and western countries including Indonesia. And this bond is based on a profit-sharing agreement and partnership/partnership. Moreover, Indonesia is a largely Islamic country, but Malaysia and Singapore lead Indonesia in issuing Islamic bonds.

\section{c. Fines or cash penalties and administrative costs}

\section{Cash fines or penalties}

A fine in the form of money charged to a person who is in debt is something that is not yet exemplified by the Salaf generation. It may well be because the law is not permissible, or it could because the era did not require a fine in the form of money. So, it is not surprising if the ulamas differ in opinions in this matter, and every opinion has a ground for argument.

\section{Cash penalty which constitutes as absolute haram}

Ulama 'agreed that the cash penalty that is levied against those with difficulty paying debts is haram. A trading company that engages in this unlawful transaction without definitive law from a judge is gravely despicable because it constitutes an unjust crime and mistreatment to the public. Religion provides solutions for people who do not have assets and have debt obligations, for example by al-hajr al-Mâly (boycotting the use of assets). It prohibits the use of assets belonging to the borrower until he can return his debt. In a case of uncertainty in paying the debts, Syarî'at recommends the lender to forgive the loan and turn it into shadaqah as an act of kindness towards those in need. A government can also transfer the burden of debt by paying it from bait al-mâl (Muslims fund). There is yet guidance from Syarî'at in terms of cash penalty for those with difficulties in paying debts. 


\section{Cash penalty differs among the ulamas' opinions}

Scholars disagree about the legality of cash fines for rich people who are reluctant to pay debts. Does the law permit it? Scholars agree in the punishment of the rich who are reluctant to pay debts, because Prophet Muhammad, Peace is upon him, said:

( مطل الغني ظلم ، وقال : لي الو اجد يحل عرضه وعقوبته ).

Meaning: "Deferring payment of debt for the rich is tyrannical, he said:" A capable person who delays repaying his debt, then honor and punishment has been lawful for him." (al-Bukhary, no. 2400, 2401). So some scholars allow it and some forbid it, and each opinion has its reasonings and counter-arguments.

\section{Those in view that it is permissible to penalize the riches in cash fines should they become a reluctant loan payer}

Scholars who allow cash fines for rich people, who are reluctant to pay debts, rely on the hadith mentioned above. Because tyranny is a punishable crime. In this case, the punishment is general unless otherwise there is a dalil to support its specific wordings to on the rulings, such as how much cash is used to penalize? Tahakkum refers to as enforcing litigation without sound argument based on dalil.

There is no ijma 'that prohibits cash fines (as presumed by those who forbid it), but this includes opinions which scholars disagree on whether to allow it or to forbid. It may well be that the correct opinion is what Ibn Qayyim mentioned - that the law depends on the benefit. To resolve the issue is to rely on the Imam's ijtihad. (al-Mushlih and al-Shâwy, 1422 H/2001 M, 302)

Ibn al-Qayyim said: then this is a case that is returned to the Imam's ijtihad and depending on the benefit because the Shari'ah does not give a general order nor does it give a measure that cannot be added or subtracted. Therefore, the scholars differ in opinion in determining the law. And the truth is that the law refers to a similar argument above because no argument shows the naskh (deleting), and the practice of Khulafä 'alRāsyidun (the four caliphates after prophet Muhammad) and other ulamas thereafter. (al-Jawziyah, 118)

\section{Those in the opinions disallowing cash penalty to be imposed on the rich who are reluctant to repay debt}

They believe that fines imposed on both the rich and not rich in a form of cash currency are haram, because the practice will lead to ribâ. There is also no example from salaf sholif relating to imposing cash fines on the rich. This constitutes innovation (bid'ah) that is prevalent in today's world.

Among the arguments of this group is that the practice should give priority to things that are doubtful on certain matters. The fines by which taking many assets is a certain matter, while the benefits obtained by the creditor if there is no delay in debt 
payments is an uncertain matter. So it comes down to prioritizing things that are not certain over those with no definitive value in the Shari'a.

Another argument is that cash fines due to delays in debt repayments are similar to taking off other people's mistakes to seek personal gains. This is no different than asking for additional payments due to delays in a grace period or when money is taken by the creditors. There is a rule: which is considered to be the intent and purpose only. And another argument of this group, it is feared that people will be taking advantage of the debt they provide, on the pretext that it is a monetary fine,p. So this argument supports the idea for a minimum prevention effort.

In my opinion, the most diligent and correct opinion is the opinion that prohibits cash fines to the rich who are reluctant to pay debts, because there are many propositions, including prevention efforts that potentially lead to the practice of usury. The rules: what is considered is the purpose which is not resolution wordings. But, there are exceptions when at certain times a judge may impose a cash fine to the rich who are reluctant to pay debts, alt this is not absolute. With several conditions, including a careful in-depth study and case study must be conducted, in addition to estimating losses suffered by the creditor due to the reluctance of the indebted party. Most important is that cash penalty fines should be allocated to services for the public interest.

\section{Administrative fee}

Before discussing in detail, we must fully understand that every bank - sharia or conventional - is a commercial institution and not a social enterprise, making each bank to act as intermediaries between investors or funder and employees. The conventional bank uses interest-based loans with a fixed maturity date as the primary product.

Undoubtedly, sharia bank is synonymous with interest-free based lending and avoids ribâfadhl (sales or exchanged contract). One of its primary products is Qardh hasan or interest-free based lending. As a commercial entity, the question then arises in contemplating the validity of imposing the borrower a burden with the huge administrative fee?

Ulamas unanimously agree that a lender is prohibited to request funding from the borrower as a service fee or unjustified compensation.

There are dissenting opinions, however, on a matter when a commercial company such as a bank is the lender. Among the ulamas, some allow a provision for the administrative fee as a service charge but not as to prolong loan maturity date. The fee is also used to pay for employees, who provide services to lenders. Therefore, lenders must shoulder the burden of paying lending service charges, including administrative fees.

The ulamas who do not conform to the use of administrative fee incline to believe, arguing that the provision is manipulative to gain ribâ. Therefore, this is similar to bank interest. A company takes profits by imposing on the administrative fee of 
which can minimize monthly operational overhead. Another argument states this effort does not prevent the practice of ribâ, since each profit gained from lending is ribâ.

To be exact, a bank must not use lending charges for an administrative fee to lead into the engagement of ribâ. This view serves as a preventive measure.

\section{CONCLUSIONS}

From the foregoing discussions, the following can be summed up:

The extreme prohibition of Ribâ and its detriment is evidenced by the clear texts of the Qur' an and Hadiths. The receiver of ribâ, the payer of interest, the one who records it, and those in support of the haram transaction is cursed by the Prophet, May peace be upon him. Additionally, becoming a brokerage in ribâ transaction is also guilty. Those who legalize ribâ become kafir; while those who consume ribâ with prior knowledge about its prohibitions and sins, will become fasiq. According to shahih Imam Bukhari and Muslim, Abu Huraira narrated the Prophet, Peace be upon him, as saying that eating ribâ (usury) falls under the seven great destructive sins.

It is therefore mandatory for each Muslim to avoid and self-guard against receiving ribâ at this day in age, where ribâ has become overwhelming widely spread, in a time of unaffordable living and escalating commodity prices, a weakening Muslims and ignorance about religious law. Abu Hurairah reported Prophet Muhammad, Peace be upon him, as saying: . (لكائتين على الناس زمان لا ييقى منهم أحد إلا أكل الربا، فمن لم يأكله أصابه من غُباره) (ل)

Meaning: "A time will come upon mankind when everyone will take ribâ and whoever does not consume it will be affected by its dust." (Abu Dawud, 3/407)

Ribâ occurs in sales purchase transactions and lending-borrowing. When a lender provides a loan to collect extra and above the original debt, or because it is based on customary practice to charge for an extra cost, or even to impose a condition on monthly/yearly interest rates. These transactions are the norms when dealing with conventional banks and investors who manage public funding. All of them are haram according to the words of Allah (2:275): (وأحلّ الله البيع وحرّم الربا)

Allah permits sales and purchase as halal, while prohibiting ribâa

Ribâ is haram everywhere regardless of location, either it is in a Muslim country or not. The prohibition on ribâ is generally absolute and without limitations nor specifications. The author's article clearly defines ribâ and loan, their implications and reasonings (dalîl), and the consensus of the ulama relating to Qardh Ribâ (interest loan) from seven schools of thought. 


\section{REFERENCES:}

Al-Bukhāri, Muhammad bin Ismâ'il. (1414). Al-Jâmi' al-Sahîh. Damaskus: Dâr Ibn Katsîr

Al-Jauziyah, Ibnu Qayyim Muhammad bin Abi Bakar. (1977). A'lâm al-Muwaqqi'în 'an Rabbi al-'Alamîn. Beirut: Dâr al-Fikr

Al-Bahawtiy, Manshur bin Yunus bin Shalah. Al-Rawdh al-Murabba' Syarah Zâd alMustaqni', Beirut: Mu`assasah al-Risâlah.

Al-Jarullâh, 'Abdullah bin Jarullâh Ibrâhim. (1989). Min Ahkâmi Fiqhi al-Islâmî wa Mâ Jâ'a fî̀ Mu'âmalât al-Ribawiyyah,

Al-Jauharî, Ismâ'il bin Hammad. Al-Shihâh Tâj al-Lughah wa Shihâh al-'Arabiyyah. Beirut: Dâr al-Malâyîn

Al-Dardîr, Ahmad bin Muhammad. Al-Syarh al-Shaghîr,

Al-Dzahabi, Syamsuddîn Abu 'Abdillah Muhammad bin Ahmad bin Utsman. (2008). Al-Kabâ ir. Cairo: Dâr al-Muqattam lî al-Nasyr wa al-Tauzî'

Al-Maqdisî, Ibnu Qudâmah, (1988). Al-Mughnî. Riyadh: Dâr 'Alam al-Kutub

Al-Mushlih, 'Abdullah dan Shalah Shâwi. (2001). Mâ lâ Yasa'u al-Tajîr Jahluhu. Riyadh: Dâr Muslim

Al-Salûs, 'Ali Ahmad. Al-Iqtishâd al-Islâmî wa al-Qadhâyâ al-Fiqhiyyah al-Mu'âshirah, Mesir: Dâr al-Taqwâ

Al-Sarkhasî, Abu Sahl Muhammad Ahmad Abi Sahl. (1335). Syarh al-Siyar al-Kabîr.

Al-Syâfi'î, Muhammad bin Idrîs. (1321). Al-Umm. Cairo: Al-Mathbû'ah al-Maymaniyah

Al-Syarbînî, Syamsuddîn Muhammad bin al-Khatîb. (1997). Mughnî al-Muhtâj. Beirut: al-Thab'ah al-ûla.

Al-Syawkânî, Muhammad bin 'Alî. (1357). Nayl al-Authâr Syarh Muntaqâ al-Akhbâr min Ahâdîts Sayyid al-Akbâr. Mesir: Al-Mathba'ah al-Utsmâniyyah al-Mishriyyah

Al-Fawzan, Shalih bin Fauzan bin 'Abdullah. (1990). Al-Farqu baina al-Bay' wa al-Ribâ fî al-Syarî'ah al-Islâmiyyah. Riyadh: Jâmi'ah al-Imâm Muhammad bin Sa'ûd alIslâmiyyah

Al-Shan'ânî, Muhammad bin Ismâ'îl al-Amir al-Yamânî. (1999). Subul al-Salâm Syarh Bulûgh al-Marâm min Jam'i 'Adillah al-Ahkâm. Beirut: Dâr al-Kutub al-Arabî

Al-'Ibâdî, Abdullah. Mauqîfal-Syarî'ah min al-Mashârif al-Islâmiyyah al-Mu'âshirah. Beirut: Al-Maktabah al-'Ashriyyah

'Athâ', Abdulqâdir Ahmad. Hâdzâa Halâl wa Hâdzâ Harâm. Mesir: Dâr al-I'tishâm

Al-Kasânî, 'Ala' al-Dîn Abu Bakar bin Mas'ûd. (1996). Bada 'i' al-Shana 'i' fi Tartîb alSyara ' $i$ '. Beirut: Dâr al-Fikr

Al-Matrûk, 'Umar bin 'Abdul 'Azis. (1418). Al-Ribâ wa al-Mu'âmalât al-Mushrafiyyah fì Nazhâr al-Syarî'ah. Riyadh: Dâr al-'Ashimah 
Al-Mishriy, Rafiq dan Muhammad Riyadh al-Abrasî. Al-Ribâ wa al-Fa ìdah: Dirâsah Iqtishad Muqâranah. Damaskus: Dâr al-Fikr

Al-Mawdûdi, Abu al-A'lâ. (1983). Al-Ribâ. Beirut: Mu'assasah al-Risâlah

Al-Nabhân, Fâruq. Al-Qurûdh al-Intâjiyyah wa Mauqif al-Islâm minhâ.

Âlu al-Syaykh, Muhammad ibnu Ibrahim, al-Rawdhah al-Nadiyyah fi al-Radd 'ala man Ajaza al-Mu'amalāt al-Ribawiyyah, Riyadh: Mathābi' al-Qāsim, No Date

Al-Qardhâwî, Yûsuf. (1978). Al-Halâl wa al-Harâm fî al-Islâm. Beirut: Al-Maktab al-Islâmî Al-Zuhaylî, Wahbah. (2002). Al-Mu'âmalât al-Mâliyah al-Mu'âshirah. Damaskus: Dâr alFikr

Badawi, Ahmad Zaki. Mu'jâm al-Mushthalahât al-Tijâriyyah wa al-Ta'âwuniyyah, tt

Burhanuddin, Ibrahim bin Muhammad. (1997). Al-Mabda 'fi Syarh al-Muqni’. Beirut: Dâr al-Kutub al-'Ilmiyyah

Ibnu Bâz, 'Abd 'Azîz. (1995). Nasîhah 'Ammah fî at-Tahzhîr min al-Mu'amalât al-Ribawiyah. Riyadh: Dâr 'Ilmiyyah

Ibnu Taymiyah, Taqiyuddîn Ahmad. (2006). Majmû' al-Fatâwâ. Cairo: Dâr al-Hadîth

Ibnu Juzay, Abu al-Qâsim al-Gharnâthî. Al-Qawânîn al-Fiqhiyyah. No Publition.

Ibnu Hajar, Ahmad ibn Muhammad, al-Haythami. (1987). Al-Zawâjir 'an Iqtirâf alKabâ ir. Beirut: Dâr al-Fikr

Ibnu Rusyd, Muhammad ibn Ahmad, al-Andalûsî. Bidâyat al-Mujtahid wa Nihâyat alMuqtashid. Dâr al-Kutub al-Islâmiyah, No date.

Ibnu 'Abidîn, Muhammad Amin. (1994). Radd al-Mukhtâr 'ala ad-Durr al-Mukhtâr. Beirut: Dâr al-Kutub al-'Ilmiyyah

Ibnu 'Abd al-Bâr, Yusuf ibn 'Abdillâh. (1980). Al-Kâfî fî Fiqh Ahl al-Madînah al-Mâlikî. Riyâdh: Maktabat al-Riyâdh al-Hadîthah

Ibnu Dhauyaan, Ibrahim bin Muhammad bin Salîm. Manâr al-Sabîl fî Syarh al-Dalîl, AlRiyâdh: Maktabah al-Islamî

Ilâhi, Fadhl. (1986). Al-Tadâbîr al-Wâqiyah min al-Ribâ fì al-Islâm. Pakistan: Idârah Turjumân al-Islâmî

Kan'ân, 'Alî. (1997). Al-Iqtishâd al-Islâmî. Damaskus: Dâr al-Ma'ârif wa dâr al-Husnain

Manzhûr, Ibn, (2003). Lisân al-'Arab. Cairo: Dâr al-Hadîts

Muslim, Abu al-Hasan Muslim bin al-Hajjaj al-Quraysyî al-Naisaburî. (2004). Al-Jâmi' alShahîh. Cairo: Maktabah al-Shafa

Musthafa, Ibrahim, et.all. Al-Mu'jam al-Washît, Turki: Al-Maktabah al-Islâmiyyah

Musa, Muhammad Yusuf. Al-Islâm wa Musykilâtunâ al-Mu'âshirah. Cairo: Maktabah Wahbah. 
Daud Rasyid

Sâbiq, Sayyid. (1999). Figh al-Sunnah. Cairo: Dâr al-Fath lî al-I'lâm al-'Arabî

Syaltût, Muhammad. Al-Fatawa. 